\title{
"The pen is the blade, my skin the paper": risk factors for self-injury in adolescents
}

\author{
"Caneta é a lâmina, minha pele o papel": fatores de risco da automutilação em adolescentes \\ "La pluma es la hoja, mi piel el papel": factores de riesgo para la automutilación en adolescentes
}

\author{
Danielle Xavier Moraes' \\ ORCID: 0000-0001-8310-9287 \\ Érika de Sene Moreira' \\ ORCID: 0000-0001-7744-9293 \\ Johnatan Martins Sousa' \\ ORCID: 0000-0002-1152-0795 \\ Raquel Rosa Mendonça do Vale" \\ ORCID: 0000-0003-2089-8842 \\ Eurides Santos Pinho' \\ ORCID: 0000-0002-1158-8247 \\ Paula Cândida da Silva Dias"' \\ ORCID: 0000-0002-8761-0551 \\ Camila Cardoso Caixeta' \\ ORCID: 0000-0003-2479-408X
}

'Universidade Federal de Goiás. Goiânia, Goiás, Brazil "Centro Universitário de Mineiros. Trindade, Goiás, Brazil. "' Pontifícia Universidade Católica de Goiás. Goiânia, Goiás, Brazil.

How to cite this article:

Moraes DX, Moreira ES, Sousa JM, Vale RRM,

Pinho ES, Dias PCS, et al. "The pen is the blade, my skin the paper": risk factors for self-injury in adolescents.

Rev Bras Enferm. 2020;73(Suppl 1):e20200578. doi: http://dx.doi.org/10.1590/0034-7167-2020-0578

\section{Corresponding author: \\ Danielle Xavier Moraes \\ E-mail:daniellemoraes@discente.ufg.br}

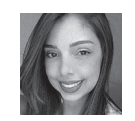

EDITOR IN CHIEF: Antonio José de Almeida Filho ASSOCIATE EDITOR: Fátima Helena Espírito Santo

Submission: 06-30-2020

Approval: 09-13-2020

\section{ABSTRACT}

Objective: to describe the risk factors that influence the self-injury behavior of adolescents assisted at a Psychosocial Care Center for Children and Adolescents, according to subjects' own perceptions. Method: a descriptive, exploratory, qualitative study carried out through medical records and a focus group with 07 adolescents. The statements were submitted to thematic content analysis. Results: in the risk factors category, four subcategories emerged: Family adversity factors; Social contagion; Adverse life events; Personal characteristics. Conflicts, lack of support, drug use in the family, meeting someone who cuts themselves, social networks, religiosity, history of sexual violence and bullying were identified as risk factors that influence self-injury. Final considerations: adolescents pointed out the need for prejudicefree dialogues in schools, in health and family devices, configuring protective factors to avoid this practice that comes from several negative events throughout life.

Descriptors: Adolescent; Self Mutilation; Risk Factors; Mental Health; Community Mental Health Services.

\section{RESUMO}

Objetivo: descrever os fatores de risco que influenciam o comportamento da automutilação de adolescentes em atendimento em um Centro de Atenção Psicossocial Infantojuvenil, na percepção do próprio sujeito. Método: estudo descritivo, exploratório, de abordagem qualitativa, realizado por meio de prontuários e grupo focal com 07 adolescentes. Os depoimentos foram submetidos à análise temática de conteúdo. Resultados: na categoria Fatores de risco, surgiram quatro subcategorias: Fatores de adversidade familiar; Contágio social; Acontecimentos adversos de vida; Características pessoais. Conflitos, falta de suporte, uso de drogas na família, conhecer alguém que se corta, redes sociais, religiosidade, histórico de violência sexual e bullying foram identificados como fatores de risco que influenciam na automutilação. Considerações finais: as adolescentes apontaram para a necessidade de diálogos livres de preconceitos nas escolas, nos dispositivos de saúde e família, configurando fatores de proteção para evitar essa prática que advém de diversos acontecimentos negativos ao longo da vida.

Descritores: Adolescente; Automutilação; Fatores de Risco; Saúde Mental; Serviços Comunitários de Saúde Mental.

\section{RESUMEN}

Objetivo: describir los factores de riesgo que influyen en la conducta de automutilación de adolescentes atendidos en un Centro de Atención Psicosocial para niños y adolescentes, según la percepción del propio sujeto. Método: estudio descriptivo, exploratorio con abordaje cualitativo, realizado a través de historias clínicas y un grupo focal con 07 adolescentes. Los testimonios fueron sometidos a análisis de contenido temático. Resultados: en la categoría Factores de riesgo surgieron cuatro subcategorías: Factores de adversidad familiar; Contagio social; Eventos de vida adversos; Características personales. Los conflictos, la falta de apoyo, el uso de drogas en la familia, el encuentro con alguien que se corta, las redes sociales, la religiosidad, un historial de violencia sexual y bullying fueron identificados como factores de riesgo que influyen en la autolesión. Consideraciones finales: los adolescentes señalaron la necesidad de diálogos libres de prejuicios en las escuelas, en los dispositivos de salud y familiares, configurando factores protectores para evitar esta práctica que proviene de varios eventos negativos a lo largo de la vida.

Descriptores: Adolescente; Automutilación; Factores de Riesgo; Salud Mental; Servicios Comunitarios de Salud Mental. 


\section{INTRODUCTION}

Adolescence is a period of human development characterized by hormonal changes, which result in physical, social, cognitive changes and emotional and behavioral reactions ${ }^{(1)}$. The study of adolescence is recent, started in the $20^{\text {th }}$ century with Stanley Hall's theories ${ }^{(2)}$, which considered this phase to be a stage of conflict and intense psychological suffering. Hall brought a negative image of adolescence because he believed that little could be done to change the adversities of this period, in addition to giving little space for the influences of the environment.

On the other hand, according to Erik Erikson's stages of psychosocial development ${ }^{(3)}$, he suggests that the environment participates in personality construction, associating psychoanalysis with cultural anthropology, linking the intellectual, socio-cultural, historical and biological dimensions in order to emphasize the influence of environments and social experiences in life development. When it came to adolescence, the theme of identity was addressed ${ }^{(3)}$, which constantly changes and is influenced by experiences, information obtained in relationships, sexuality, and values. Therefore, he pointed out that constructing a human being's personality is influenced by society and groups, whose individuals are part of.

In this study, a look directed at adolescents was based on the Theory of Human Development ${ }^{(3)}$, which considers the subject as an essentially social being who lives in a group and is influenced by it. This study was carried out in the light of Social Determinants of Health, which approach that economic, social, cultural ethnic/ racial, psychological and behavioral factors influence individuals' health, with the possibility of becoming a risk factor for the development of diseases ${ }^{(4)}$.

We know that several emotional, contextual and social factors can lead to behaviors that are harmful to adolescent health, such as self-injury. This behavior, despite occurring in different age groups, is more common in adolescents between 13 and 14 years of age, and may last for 10 or more years ${ }^{(5)}$.

Self-injury is described as a complex phenomenon, with great variation in terms of nomenclature, concept, prevalence, origin and determinants ${ }^{(6)}$. Currently, studies on this behavior are divided into two groups, which are distinguished, mainly, according to the intentionality of the act, which are: deliberate self-harm, which includes all methods of self-harm, not differentiating whether it is a suicide attempt ${ }^{(7)}$ and Nonsuicidal Self-Injury (NSSI), which refers to injuries such as cuts, burns and scratches, referring only to the destruction of tissue with no intention of death ${ }^{(8)}$.

According to the International Classification of Diseases (ICD$10)^{(9)}$, self-injury is understood as a symptom of some mental disorders. However, the $5^{\text {th }}$ Diagnostic and Statistical Manual of Mental Disorders (DSM-V) ${ }^{(10)}$ proposed that self-injury should be classified as a separate diagnosis, suggesting the nomenclature "non suicidal self-injury".

Guerreiro and Sampaio(11) present the term "self-injurious behavior", defining it as a behavior with a non-fatal result, in which an individual deliberately presents actions that intend to cause injuries to his or her own body. This same nomenclature is also presented in the National Suicide Prevention Plan (Plano Nacional de Prevenção de Suicídio) 2013/2017(12), prepared by the government of Portugal, which aims to standardize terminologies, improve the recording of suicidal acts and, in the long term, reduce self-injurious and suicidal acts. In this plan, the authors define self-injurious behavior as a behavior without suicidal intentionality, but which involves intentional self-injurious acts.

In summary, at present, self-injury in adolescents is considered as the result of complex interactions between genetic, biological, psychiatric, psychological, social and cultural factors, becoming a relevant public health problem ${ }^{(11)}$.

National and international studies address the reasons that lead individuals to self-harm. Among the most common causes are the attempt to modulate the emotional reactions that are intense and common in adolescence, the low ability to solve problems, the difficulty of communication, a low tolerance to stress and the increased sensitivity to negative emotions, as it seeks to a need for extreme behavior to deal with these situations ${ }^{(5,13-16)}$.

In the setting of psychosocial care, the Psychosocial Care Centers for children and adolescents are specialized health services to care for children and adolescents with intense psychological distress ${ }^{(17)}$, including due to self-harm. These specialized services seek to work on the autonomy, limits and potential of individuals who seek care, always aiming to promote activities at the collective and individual level, inserting the family in care and based on the principle of intersectoriality ${ }^{(18)}$.

Given the context of self-harm as a global public health problem, it is important to carry out studies on this topic considering the impacts resulting from this practice in individuals' future lives and the interest in the search for factors triggering self-harm to identify possible prevention actions.

\section{OBJECTIVE}

To describe the risk factors that influence the self-injury behavior of adolescents assisted at a Psychosocial Care Center for Children and Adolescents, according to subjects' own perceptions

\section{METHODS}

\section{Ethical aspects}

The research followed the ethical recommendations of Resolution 466/2012 of the Brazilian National Health Council (Conselho Nacional de Saúde) ${ }^{(19)}$. It was approved by the Human Research Ethics Committee at UFG. To promote the confidentiality of the participants' identity, they were coded by letter A (adolescents) and numbers from 1 to 7 .

\section{Type of study and theoretical-methodological framework}

This study is part of a dissertation entitled " $A$ automutilação em adolescentes: um olhar sobre a concepção do sujeito, da familia e do profissional de saúde", which was presented to the Graduate Program in Public Health at Universidade Federal de Goiás, developed along the lines of descriptive, exploratory and qualitative research.

The main objective of this descriptive study is to observe, describe and record characteristics of certain populations or 
phenomena. Moreover, the exploratory character seeks, through detailed investigation, to improve ideas, build hypotheses, discover intuitions in order to make the subject more illuminating and evident ${ }^{(20)}$.

Based on the psychosocial care model, this article addresses a discussion aimed at affirming the citizenship of the person with mental disorder and valuing the reorganization of their existence based on rights and autonomy based on the institutionalization of policies contrary to the psychiatric hospitals dominance model ${ }^{(21)}$.

The survey followed the steps recommended by the Consolidated Criteria for Reporting a Qualitative Survey (COREQ) (22).

\section{Study setting}

This research was carried out at a Child and Adolescent Psychosocial Care Center (CAPSi - Centro de Atenção Psicossocial infantojuvenil) in a municipality in the metropolitan region of Goiânia, Goiás, Brazil, from June to October 2017. CAPSi are specialized psychosocial care services, whose care is aimed at children and adolescents who have some moderate or severe psychological distress or for those who need care resulting from the abusive use of alcohol and other drugs ${ }^{(18)}$.

\section{Data source}

Participants were selected from the documentary research carried out through the analysis of medical records, detailed reading of the history and evolution of the treatment. Adolescents from 12 to 18 years old, of both sexes, with at least one report of selfinjury episode and who were regularly attending CAPSi activities during the data collection period were included.

The unit had 329 active users in July 2017. Of these, 167 were in the 12 to 18 age group. After analyzing the 167 medical records, we excluded the medical records of users with intellectual deficit and autism. According to the DSM-V, self-harm performed by individuals with developmental disorders is part of a pattern of repetitive stereotypes ${ }^{(10)}$; therefore, they were not included in the research. Then, 42 records remained, among which we identified 27 records of adolescents who had reported at least one episode of self-injury.

Subsequently, guardians were contacted according to the information in medical records. After parents' authorization, 20 adolescents were invited to attend CAPSi for the focus group. Of these, eight came after the research was clarified and one of the adolescents refused to participate, justifying that the father had not told what it was about and that he did not like to expose personal matters. The adolescent was welcomed in her decision and accompanied to the guardian's presence. Thus, 7 adolescents participated in the focus group, all female. The path to the selection of adolescents is illustrated in Figure 1.

\section{Data collection and organization}

Data collection took place through documentary research in medical records and a focus group with adolescents.

For the documentary research, an instrument was used, built to extract data from the medical records and from them to know who the adolescent with self-injury behavior is. The instrument consisted of three parts: sociodemographic data (gender, age, place of residence, income from religion, education), psychosocial aspects (studying, school complaints, substance use, bullying, violence) and psychopathological symptoms (diagnosis, ideation suicidal, sleep, sadness, social isolation, sexuality, self-injury methods).

The execution of the focus group was attended by four members of the Interdisciplinary Group for Research and Intervention in Mental Health, Reflect for Care (RECUID (Grupo Interdisciplinar de Pesquisa e Intervenção em Saúde Mental, Refletir para Cuidar)/ UFG). The group's coordination was conducted by two nurses specialized in Group Dynamics and Team Management, with assistance of the responsible researcher specialized in mental health and by a nursing academic, who took notes in field diary.

The focus group started with a coexistence contract, in order to favor and contribute to the organization of the activity. To warm the group up, adolescents were invited to present themselves with a name and an adjective that characterizes it and begins with the letter of their name. Then, the "Empty Doll" group technique was proposed, which consisted of a paper representation of their own body, in which the head composed thoughts, the heart expressed feelings and the limbs portrayed attitudes about self-injury. The assessment of coordination between thinking, feeling and attitude was guided by the phrases: "When I self-harm, I think..."; "When I self-harm, I feel..."; "The desire, the will, the need for self-injury appear when..."; "It started in my life when ...." The adolescents were able to choose songs to perform the reflective exercise. 
After finishing the drawings, the processing started with the presentation of the drawings and the following guiding questions: "What is self-injury for you?"; "How did you start self-harm?"; "In what situations do you self-harm?"; "How do you feel before, during and after self-injury?". To finish the focus group, a strategy was used that consists of using signs with emotions figures, from which they were distributed to each participant to choose one, defining how they were leaving that activity. To record the focus group, a digital recorder was used, and the lines were later transcribed in full.

\section{Data analysis}

Data analysis was based on thematic content analysis, defined as a set of communication analysis techniques that allow inference about data in a given context through specialized and scientific methods, allowing them to be replicable and valid ${ }^{(23)}$.

In the first stage, pre-analysis, transcription of the focus group and text skimming was performed. In the second stage, material exploration, units of meaning were identified, which were grouped into categories and subcategories. In the last step, treatment of results and interpretation, networks of relationships between units of meaning were built, facilitating the understanding of data ${ }^{(23)}$.

\section{RESULTS \\ Characterization of adolescents in the focus group accord- ing to data from medical records}

The 7 participants in the focus group were female, aged between 13 and 18 years, with an average age of 15 years. In regards to family typology, 2 adolescents came from nuclear families (composed of a man and a woman with at least one child), 2 from single parents (composed of a single parent with children) and 2 from reconstituted families (remarriage), based on Kaslow classification ${ }^{(24)}$.

As for diagnoses, 5 had some type of mood disorder according to the International Classification of Diseases and Health-related Problems ( 3 with Bipolar Affective Disorder, 2 with Depressive Episode) and 2 adolescents with a diagnosis of Anxiety Disorder.

\section{Categorization}

According to content analysis, senses and meanings of participants' statements were grouped into categories and subcategories that reveal the risk factors for self-injury in adolescents assisted at CAPSi. The focus of this study focuses on Risk factors, in which Family adversity factors, Social contagion, Adverse life events and Personal characteristics emerged, bringing adolescents' perceptions about risk factors for self-injury in adolescence. The following charts show the units of meaning with their respective illustrative statements for each subcategory.

\section{Family adversity factors}

Several difficulties in living with family members reveal influence on the self-injury behavior of adolescents, relating this act to unfavorable situations that occur in the family context and that compromise the positive development of adolescence as illustrated by statements in Chart 1 .
Chart 1 - Family adversity factors that contribute to self-injury in adolescence, Aparecida de Goiânia, Goiás, Brazil, 2017

\begin{tabular}{|l|l|}
\hline Units of meaning & Illustrative statements \\
\hline Family conflict & $\begin{array}{l}\text { The last time I cut myself, I was upset about some } \\
\text { things that had happened at home, some fights } \\
\text { between my parents. (A3) }\end{array}$ \\
\hline $\begin{array}{l}\text { Lack of family } \\
\text { support }\end{array}$ & $\begin{array}{l}\text { One thing that differentiates people who self-harm } \\
\text { others is that everyone goes through problems, but } \\
\text { we don't have support from the family when we go } \\
\text { through these problems. (A6) } \\
\text { I told my mother that I needed help, that if I didn't } \\
\text { have help, I would die, she didn't care, she said it } \\
\text { was a adolescent thing. (A3) }\end{array}$ \\
\hline $\begin{array}{l}\text { Separation of } \\
\text { parents }\end{array}$ & $\begin{array}{l}\text { My father and my mother separated when I was } \\
\text { four years old, I missed him a lot, I think it hindered } \\
\text { me too much, I felt abandoned, divided, sad. (A3) }\end{array}$ \\
\hline $\begin{array}{l}\text { Maternal } \\
\text { rejection }\end{array}$ & $\begin{array}{l}\text { My mother said that I ruined her life, that I } \\
\text { shouldn't have been born, that I should have died } \\
\text { in childbirth, it made me sad and I cut myself, I felt } \\
\text { like garbage. (A1) }\end{array}$ \\
\hline $\begin{array}{l}\text { Alcohol and other } \\
\text { drug use in the } \\
\text { family }\end{array}$ & $\begin{array}{l}\text { I feel angry when there is a fight at home, then I cut } \\
\text { myself. I started cutting myself because of so much } \\
\text { fighting at home. I saw my father using drugs, my } \\
\text { mother fighting, breaking things at home, I was } \\
\text { getting sad, I felt a huge pain inside me. Since I was } \\
\text { little, I have wanted to change my reality, but I feel } \\
\text { that it is not just up to me and I feel helpless for it. (A1) }\end{array}$ \\
\hline
\end{tabular}

\section{Social contagion}

Adolescents claim that the development of self-injury is related to the knowledge of other people who also self-mutilate. These relationships exist in real and virtual spaces, and the reports of self-injury experiences divided in the media portray the action as an immediate way out of the problematic situations experienced. Consequently, internet users identify with statements and emotions exposed and believe in the benefit of behavior.

Chart 2 - Risk factors for self-injury in adolescence related to social contagion, Aparecida de Goiânia, Goiás, Brazil, 2017

\begin{tabular}{|l|l|}
\hline Units of meaning & Illustrative statements \\
\hline $\begin{array}{l}\text { Knowing } \\
\text { someone who } \\
\text { cuts himself or } \\
\text { herself }\end{array}$ & $\begin{array}{l}\text { I have virtual friends and real friends who cut } \\
\text { themselves. (A4) } \\
\text { At my school, there are a lot of people who cut } \\
\text { themselves. In my room, there are two more girls } \\
\text { who are getting hurt. (A5) }\end{array}$ \\
\hline Internet/social & $\begin{array}{l}\text { Self-injury started because I kept watching videos of } \\
\text { people cutting themselves. They said they felt better, } \\
\text { and I thought it would ease my anxiety. (A1) } \\
\text { I was already cutting myself when Ijoined a Facebook } \\
\text { self-injury community. I thought that, talking to } \\
\text { people who feel the same things that I feel, could } \\
\text { nelp me. It is very difficult to talk about self-injury } \\
\text { with someone who doesn't do it, the person thinks it's } \\
\text { cool, that we're trying to get attention, that nothing } \\
\text { justifies doing it. (A2) } \\
\text { Ithink these groups made me worse, they said that } \\
\text { the people who cut themselves are angels who want } \\
\text { to go home and that encourages people to commit } \\
\text { suicide. They post a lot of sad songs, with sad subtitles, } \\
\text { sad images, they are groups of bad mood. (A7) }\end{array}$ \\
\hline
\end{tabular}




\section{Adverse events in life}

Unpleasant situations that lead to physical, mental and emotional damage compromise the development of adolescence. Two adolescents associated the beginning of self-injury with the traumatic losses (murder) of loved ones such as mother and brother. They highlighted that these experiences brought feelings such as sadness, disappointment, fear, loneliness and abandonment, and, as a way of coping with these sensations, they resorted to self-injury.

Chart 3 - Risk factors for self-injury in adolescence related to adverse events in life, Aparecida de Goiânia, Goiás, Brazil, 2017

\begin{tabular}{|l|l|}
\hline Units of meaning & Illustrative statements \\
\hline Bullying & $\begin{array}{l}\text { I started cutting myself after I was a victim of } \\
\text { bullying and sexual abuse. (A7) } \\
\text { Attending school has always been difficult for } \\
\text { me, they called me a monkey, they were bullied } \\
\text { because of my hair, because of my color. I felt the } \\
\text { worst of all the girls, I felt like nothing. (A4) }\end{array}$ \\
\hline Loss of loved one & $\begin{array}{l}\text { It started after my mother died, I was very } \\
\text { young, I still needed her. I started to feel alone } \\
\text { or abandoned, I can't really say what I felt, I just } \\
\text { know it was bad. (A1) }\end{array}$ \\
\hline Sexual abuse & $\begin{array}{l}\text { I was abused by my father. After that, I cut myself } \\
\text { the first time. We even expect other people, but we } \\
\text { expect protection from beloved ones. (A3) } \\
\text { I was raped for three years and was never able to } \\
\text { say anything. My biggest pain is not being able to } \\
\text { speak, but I have a diary: the pen is the blade, my } \\
\text { skin is the paper. (A6) }\end{array}$ \\
\hline
\end{tabular}

\section{Personal characteristics}

In this subcategory, the characteristics that make up the personality and behavior of adolescents that are related to selfinjury are expressed (Chart 4).

Chart 4 - Risk factors for self-injury in adolescence related to the personal characteristics of adolescents, Aparecida de Goiânia, Goiás, Brazil, 2017

\begin{tabular}{|l|l|}
\hline Units of meaning & Illustrative statements \\
\hline Anxiety & $\begin{array}{l}\text { I have anxiety crisis, I feel short of breath, chest } \\
\text { pain, my head hurts. (A2) }\end{array}$ \\
\hline Low self-esteem & The word that defines me is loser. I'm a loser. (A1) \\
\hline $\begin{array}{l}\text { Difficulty } \\
\text { verpressing }\end{array}$ & $\begin{array}{l}\text { I wanted my family to talk to me, so I could open } \\
\text { up, I know I have a hard time talking, but if they } \\
\text { tried very well, but they don't even try. (A3) }\end{array}$ \\
\hline Social isolation & $\begin{array}{l}\text { I hardly stay in the middle of the family, I only stay } \\
\text { in the room. (A4) }\end{array}$ \\
\hline Suicidal ideation & $\begin{array}{l}\text { Iread a book that the girl cut herself and then she } \\
\text { committed suicide, I identified with her feelings. (A2) }\end{array}$ \\
\hline Sexual orientation & $\begin{array}{l}\text { I'm a homosexual, I suffer a lot because my family } \\
\text { doesn't accept it, I started cutting myself for it. It } \\
\text { is very difficult to live with a family that does not } \\
\text { accept you. (A3) }\end{array}$ \\
\hline
\end{tabular}

To be continued
"The pen is the blade, my skin the paper": risk factors for self-injury in adolescents Moraes DX, Moreira ES, Sousa JM, Vale RRM, Pinho ES, Dias PCS, et al.

Chart 4 (concluded)

\begin{tabular}{|c|c|}
\hline Units of meaning & Illustrative statements \\
\hline Religiosity & $\begin{array}{l}\text { I was not happy looking for help in the evangelical } \\
\text { church, they let me down. (A2) } \\
\text { My family is also evangelical, they don't consider } \\
\text { depression a disease, they think everything is the } \\
\text { devil. The pastor said I had a devil in my body, my } \\
\text { whole family believed, I left the church sadder. (A3) }\end{array}$ \\
\hline Anger & $\begin{array}{l}\text { I feel angry when there is a fight at home, then I } \\
\text { cut myself. I started cutting myself because of so } \\
\text { much fighting at home. (A1) }\end{array}$ \\
\hline Suicide attempt & $\begin{array}{l}\text { I told my mother that I was going to die, I said } \\
\text { I couldn't take it anymore, she didn't believe it. } \\
\text { Twice I took several medications and needed to } \\
\text { go to the hospital. (A3) } \\
\text { After I took several medications and almost died, } \\
\text { my mother sought help here. (A7) } \\
\text { After I lost my mother, I tried to kill myself several } \\
\text { times. (A4) }\end{array}$ \\
\hline Sadness & $\begin{array}{l}\text { I drew myself just as I am, with short, curly hair, a } \\
\text { smile like this, slightly sideways, forced, because } \\
\text { I can't stand smiling without wanting to. People } \\
\text { think that because I'm smiling, I'm happy, but my } \\
\text { heart is sad. (A6) }\end{array}$ \\
\hline
\end{tabular}

\section{DISCUSSION}

All study participants were composed of female adolescents, in line with international investigations that indicate that self-harm practices occur more frequently in adolescent girls ${ }^{(25)}$

Difficulties in family life, the absence of family support and maternal rejection were identified as risk factors for self-harm in adolescents. In a study carried out ${ }^{(26)}$, it was found that family inadequacy leads to inadequate development for adolescents. As a consequence, depressive symptoms and depression appear. According to a study with Australian adolescents, parental support is an important protective factor for self-harm ${ }^{(27)}$. Adolescents who do not identify parental support are more likely to develop such behavior ${ }^{(28)}$.

It is important to note that the data in this study are in line with the literature, showing that family configurations have undergone profound changes with regard to their structure. The nuclear family model is no longer a reference and we are increasingly faced with reconstituted families and single-parent families. A study carried out with adolescents with self-injurious behavior in Portugal points out that the diversity in family typology requires that health professionals respect the socioeconomic, cultural, spiritual and linguistic differences of families, so that they become partners in adolescent care ${ }^{(29)}$.

Associated with the family conflict setting, it was evidenced the use of alcohol and other drugs and violence, which trigger feelings of anger and helplessness that lead to self-injury. Some research reveals that conflicts and difficulties in family life are factors that can induce adolescents to self-harm ${ }^{(26,30-31)}$. Moreover, in an integrative literature review, in order to identify the factors associated with self-injury, we note the association of this phenomenon with the existence of friends or family members who use drugs ${ }^{(5)}$. 
Adolescents claim that the development of self-injury is related to the knowledge of other people who also self-mutilate. These relationships exist in real and virtual spaces that include the school, virtual social networks, such as Instagram and Facebook, WhatsApp application, books and series of wide dissemination with content aimed at this age group.

Collaborating with the findings of this research, scholars ${ }^{(5)}$ identified an increased chance of self-injury in adolescents when there is a history of behavior in friendship or family relationships. Likewise, another study ${ }^{(31)}$ found that the disclosure of self-injury in a group on the subject in a virtual social network became an incentive for adolescents to repeat behavior. Disclosure of photos and posts are mechanisms that strengthen identifying the situation by adolescents seeking ways to relieve feelings.

Bullying is also a risk factor for self-injury, since feelings of sadness, loss of worth, anger and anger appeared after this event. School is the main bullying setting, as it corroborates other

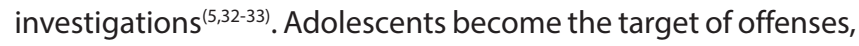
humiliation, mockery and experience feelings of loneliness, rejection, fear, depression and anger, which are incentives self-harm to relieve tension ${ }^{(5,33-34)}$. Thus, self-injury works as an ill-adapted coping mechanism for bullying ${ }^{(35)}$.

Loss of loved ones, as a mother, was related to episodes of self-injury. When analyzing the adolescents' blog narratives, researchers realized that the reference to difficult situations may result in beginning of self-injury, such as the death of a brother and the end of courtship. These facts provoke a psychic pain that is complicated to bear and to deal with, in addition to the feeling of loneliness because there is no one to share the suffering; for this reason, self-injury appears as an outlet for the relief of anguish ${ }^{(15)}$.

Regarding episodes of sexual abuse, an expression of intense suffering was also observed in body language: rigid, trembling body, tears, distant gaze and downcast. Sexual abuse against adolescents is portrayed as an aggravating risk factor for self-harm ${ }^{(30)}$, increasing the incidence of this behavior, given that the history of sexual abuse increases this risk, when compared to other types of abuse that occur in childhood ${ }^{(5)}$. A survey conducted in Israel with 93 female adolescents, aged 12 to 18 , indicated that childhood sexual abuse increases the risk of self-injury three times ${ }^{(36)}$.

Self-injury has also proved to be a practice for regulating emotions, especially anxiety. A study, aiming to deepen the knowledge of psychological aspects such as the view of oneself, the world, relationships, anxieties and emotions, and to identify signs of depression and anxiety in adolescents with self-harm behaviors manifested in the school environment, found that all the participants showed signs of anxiety, according to Beck Anxiety Inventory ${ }^{(37)}$.

Low self-esteem was also a phenomenon expressed by adolescents, which influences self-injury. A study carried out in Australia points to low self-esteem as one of the risk factors related to the beginning of self-injury ${ }^{(27)}$.

Other aspects highlighted by the adolescents were social isolation and the difficulty to express themselves verbally. Despite this, they reported a desire to talk about self-injury and other issues associated with adolescence, such as violence and bullying, as they did not recognize the school, family and CAPSi as environments for discussion, which opposes the care model in this health device. A research has shown that the difficulty of expressing emotions verbally is related to the development of self-injury in adolescents ${ }^{(38)}$, which reinforces our findings. Moreover, an investigation in a self-injury group identified that social isolation is one of the factors that highlight the vulnerability of adolescents to self-harm ${ }^{(31)}$.

In this regard, the scientific literature reveals that the feeling of loneliness experienced by adolescents is opposed to their desire to belong to some group. They also highlight the importance of qualified and empathetic listening ${ }^{(15-16,30,39)}$.

Suicidal ideation was pointed out by the adolescents as a harbinger of self-injury. Some studies have associated self-injury with suicidal ideation and/or attempted suicide ${ }^{(16,26)}$. In this bias, researchers stated ${ }^{(26)}$ that $50.6 \%$ of participants felt like dying. Of these, $26.7 \%$ have already thought about doing something and $19.1 \%$ report having done it. Thus, individuals who exhibit self-injury behavior need frequent care and evaluation, since they must be considered as a group with a high risk of suicide ${ }^{(40)}$.

Unlike this finding, there are those who consider that selfinjury does not have a suicidal purpose, because the existing relationship is between the body itself and the expression of feeling, not in the idea of death ${ }^{(5,15)}$. In a similar study ${ }^{(41)}$, it was found that most of adolescents (61.22\%) practiced self-injury and had no suicidal intention.

Sexual orientation is approached by adolescents in a clear and objective way. Some associated self-injury with this issue, as they stated that not being accepted by the family causes suffering. This relationship was also highlighted in a previous research ${ }^{(5)}$, by pointing out that the rates of this self-injurious behavior are higher in those who have concerns about sexual orientation.

In the scientific literature, there are reports that religious backgrounds can act as a protective actor, since adolescents with this habit have the practice of attenuated self-injury ${ }^{(13)}$. Religiosity was identified as a risk factor for adolescents, evidenced by reports of demonization of depression signs and symptoms, as well as approaches that accentuate low self-esteem and sadness in adolescents.

The feeling of anger generated by dysfunctional family relationships was associated as a triggering factor for self-injury. An investigation carried out with the objective of understanding the statements of teachers and students of state public schools in Recife on self-injury identified in the reports that anger is one of the triggers for self-injury behavior, in the sense of promoting physical pain due to emotional suffering ${ }^{(30)}$.

\section{Study limitations}

The time required for data collection and analysis made it impossible to carry out a multifactorial approach to aspects related to self-injury, such as issues related to devices that involve the territory where adolescents are, such as church, school and other social spaces. Moreover, the detailed analysis of the work processes of the institution involved denotes the demand for other studies with these approaches.

\section{Contributions to health and nursing}

As this is a study carried out at a CAPSi, which has nursing staff as a team, a professional category that is directly involved 
in the care of adolescents and their families, it is essential that nurses develop skills that permeate from psychological suffering to self-injury. Another contribution is to minimize, in the medium and long term, the suffering and behavior of adolescents prone to the risk of self-injury by performing the nursing process.

This study brings contributions of important aspects that should be addressed by the institutions that educate health professionals working at CAPSi, to offer effective assistance that is capable of promoting actions of prevention, promotion and psychosocial rehabilitation of adolescents who practice self-injury and their family/companions. Furthermore, it can also contribute to the aggregation of knowledge about suicidal and self-harming behavior, as well as its nuances, ranging from states of depression, isolation, not being able to deal with anger affects, to low tolerance to frustrations, in which self-injury is attributed as a way of relieving emotional tensions that cannot be elaborated and thought out. Based on this knowledge, nursing professionals will be able to think, together with users and family members, the qualified nursing process that achieves the proposed goals and objectives.

\section{FINAL CONSIDERATIONS}

Self-injury in adolescents has several risk factors that interfere with healthy development, being related to social, psychological, subjective, emotional, family and contextual issues. Among them, adverse life events were identified, such as sexual abuse and bullying, social contagion through real and virtual environments, family issues, such as conflicts and lack of family support, as well as low self-esteem, sadness, difficulty to express themselves verbally. and sexual orientation.

This study showed that CAPSi, although it is a specialized service in caring forchildren and adolescents, presented weak strategies for systematizing dialogue on self-injury with adolescents; this distances professionals from their reality. The moments of conversation lead to the identification of risk factors, consequently to the prevention and minimization of their occurrence.

Another aggravating factor is linked to the fragility of family relationships, as family support is a powerful protective factor for self-injury. Therefore, it is necessary to understand the importance of love, dialogue, interest in adolescents' experiences, meet friends and social networks, pay attention to the relationship with school and other environments they attend to understand the physical, social and emotional needs of this group. Thus, after knowing adolescents, it is possible to identify risk factors during this period of life, and, therefore, promote healthy development and offer adequate support.

It is pointed out a need to conduct more studies that contemplate self-injury in adolescence in the individual and family context, as well as in their school territory and in health devices such as CAPSi and Primary Health Care. As it is a multifactorial demand to identify and to prevent the risk factors of self-injury, several actors are needed with the same objective. There is the possibility of carrying out health education with this public in their territory on themes related to adolescence, in order to offer qualified listening and, if necessary, to make appropriate referrals. Therefore, it is essential to build protective factors against self-injury in adolescence.

\section{FUNDING/ ACKNOWLEDGMENT}

We would like to thank the Research Support Foundation of Goiás State (FAPEG - Fundação de Amparo à Pesquisa do Estado de Goiás) for the financial support; to the Research Center RECUID (Refletir para Cuidar): Interdisciplinary Group for Research and Intervention in Mental Health at the Faculty of Nursing (FAN) of Universidade Federal de Goiás (UFG); and to Fernanda Costa Nunes, member of RECUID, for the authorship of the "Empty Doll" technique used in data collection.

\section{REFERENCES}

1. Silva AMB, Silva MLB, Emuno SRF. Relações entre o hormônio cortisol e comportamentos de adolescentes: uma revisão sistemática. Psicol Rev. 2017;26(2):337-62. doi:10.23925/2594-3871.2017v26i2p.337-362

2. Hall GS. Adolescence: its psychology and its relations to physiology, anthropology, sociology, sex, crime, religion and education (Vol. 2). New York: D. Appleton and Company; 1904. 796 p.

3. Erikson EH. Identidade, juventude e crise. $2^{\mathrm{a}}$ ed. Rio de Janeiro: Zahar; 1976. 324 p.

4. Buss PM, Pellegrini Filho A. A Saúde e seus Determinantes Sociais. Physis (Rio J.) 2007; 17(1):77-93. doi: 10.1590/S0103-73312007000100006

5. Silva AC, Botti NCL. Comportamento autolesivo ao longo do ciclo vital: revisão integrativa da literatura. Rev Port Enferm Saúde Mental. 2017;(18):67-76. doi: 10.19131/rpesm.0194

6. Hawton K, Sauders KE, O'connor RC. Self harm and suicide in adolescentes. Lancet 2012;(379):2373-82. doi: 10.1016/S0140-6736(12)60322-5

7. Skegg K. Self-harm. Lancet. 2005;366(9495):1471-83. doi: 10.1016/S0140-6736(05)67600-3

8. Nock MK, Joiner TE, Gordon KH. Non-suicidal self-injury among adolescents: Diagnostic correlates and relation to suicide attempts. Psychiatry Research. 2006;144(1):65-72. doi: 10.1016/j.psychres.2006.05.010

9. Organização Mundial de Saúde. Classificação Estatística Internacional de Doenças e Problemas Relacionados à Saúde - CID-10 [Internet]. $8^{a}$ ed. São Paulo: Edusp; 2008[cited 2020 May 17]. Available from: http://www.datasus.gov.br/cid10/v2008/cid10.htm

10. American Psychiatric Association. DSM-5: Manual diagnóstico e estatístico de transtornos mentais [Internet]. $5^{\text {a }}$ ed. Porto Alegre: Artmed; 2014[cited 2020 May 17]. 948 p. Available from: http://www.niip.com.br/wp-content/uploads/2018/06/Manual-Diagnosico-e-Estatistico-deTranstornos-Mentais-DSM-5-1-pdf.pdf 
11. Guerreiro DF, Sampaio D. Comportamentos autolesivos em adolescentes: uma revisão da literatura com foco na investigação em língua portuguesa. Rev Port Saude Publica. 2013;31(2):213-22. doi:10.1016/j.rpsp.2013.05.001

12. Ministério da Saúde (BR). Programa Nacional para a Saúde Mental. Plano Nacional de Prevenção do Suicídio $2013-2017$ [Internet]. Lisboa: Direção Geral da Saúde, 2013[cited 2020 May 17]. Available from: https://www.dgs.pt/documentos-e-publicacoes/plano-nacional-deprevencao-do-suicido-20132017-pdf.aspx.

13. Lenkiewicz K, Racicka E, Bryńska A. Self-injury-placement in mental disorders classifications, risk factos and primary mechanisms: review of the literature. Psychiatr Pol. 2017;51(2):323-34. doi: 10.12740/PP/62655

14. Costa RP, Peixoto AL, Lucas CC, Falcão DN, Farias JT, Viana LF, et al. Profile of non-suicidal self-injury in adolescents: interface with impulsiveness and loneliness. J Pediatr. 2020. doi: 10.1016/j.jped.2020.01.006

15. Fortes I, Macedo MMK. Automutilação na adolescência - rasuras na experiência de alteridade. Psicogente. 2017; 20(38):353-67. doi: $10.17081 /$ psico.20.38.2556

16. Lopes LS, Teixeira LC. Automutilações na adolescência e suas narrativas em contexto escolar. Estilos Clin. 2019;24(2):291-303. doi: 10.11606/ issn.1981-1624.v24i2p291-303

17. Ministério da Saúde (BR). Secretaria de Atenção à Saúde. Departamento de Atenção Especializada e Temática. Centros de Atenção Psicossocial e Unidades de Acolhimento como lugares da atenção psicossocial nos territórios: orientações para elaboração de projetos de construção, reforma e ampliação de CAPS e de UA [Internet]. Brasília (Brasil): Ministério da Saúde; 2015[cited 2020 May 17]. Available from: http://bvsms.saude.gov.br/bvs/publicacoes/centros_atencao_psicossocial_unidades_acolhimento.pdf

18. Quintanilha BC, Belotti M, Tristão KG, Avellar LZ. A produção do cuidado em um centro de atenção psicossocial infantojuvenil. Mental [Internet]. 2017 [cited 2020 May 17];11(20):261-78. Available from: http://pepsic.bvsalud.org/scielo. php?script=sci_arttext\&pid=S1679-44272017000100014\&lng=pt\&nrm=iso

19. Ministério da Saúde (BR). Conselho Nacional de Saúde. Comissão Nacional de Ética em Pesquisa. Resolução no 466/2012. Aprova diretrizes e normas regulamentadoras de pesquisas envolvendo seres humanos [Internet]. Brasília: Ministério da Saúde; 2012 [cited 2020 May 17]. Available from: https://bvsms.saude.gov.br/bvs/saudelegis/cns/2013/res0466_12_12_2012.html

20. Polit DF, Beck CT. Fundamentos de pesquisa em enfermagem: avaliação de evidências para a prática da enfermagem. 9a ed. Porto Alegre: Artmed; 2019. $456 \mathrm{p}$.

21. Amarante P. Saúde Mental e Atenção Psicossocial. 4a ed. Rio de Janeiro: Fiocruz; 2015. 123 p.

22. Tong A, Sainsbury P, Craig J. Consolidated criteria for reporting qualitative research (COREQ): a 32-item checklist for interviews and focus groups. Int J Qual Healthcare. 2007;19(6):349-57. doi: 10.1093/intqhc/mzm042

23. Bardin L. Análise de conteúdo: edição revista e ampliada. São Paulo: Edições 70; 2016. 280 p.

24. Kaslow FW. Families and Family psychology at the millennium. Intersecting crossroads. Am Psychol. 2001;56(1):37-46. doi:10.1037/0003-066x.56.1.37

25. Silva YA, Aguiar SG. Adolescência e automutilação no CAPS infantojuvenil de Iguatu-CE: um estudo psicanalítico. Cad Bras Saúde Mental [Internet]. 2020 [cited 2020 May 22];12(31):245-68. Available from: https://periodicos.ufsc.br/index.php/cbsm/article/view/69761/ 43297

26. Mesquita C, Ribeiro F, Mendonça L, Maia A. Relações familiares, humor deprimido e comportamentos autodestrutivos em adolescentes. Revista de Psicologia da Criança e do Adolescente [Internet]. 2011 [cited 2020 May 15];(3):97-109. Available from: http://repositorio.ulusiada. pt/bitstream/11067/115/1/rpca_n3_artigo_6.pdf

27. Andrews T, Martin G, Hasking P, Page A. Predictors of onset for non-suicidal self-injury within a school-based sample of adolescents. Prevent Sci. 2014;15(6):850-59. doi: 10.1007/s11121-013-0412-8.

28. Wolff JC, Frazier EA, Esposito-Smythers C, Becker SJ, Burke TA, Cataldo A, Spirito A. Negative cognitive style and perceived social support mediate the relationship between aggression and NSSI in hospitalized adolescents. J Adolesc. 2014;37(4):483-91. doi: 10.1016/j.adolescence.2014.03.016

29. Trinco ME, Santos JC. A família do adolescente com comportamento autolesivo internado no serviço de urgência de um hospital pediátrico. Estudo de caracterização sociodemográfica. Rev Esp Enferm Salud Mental. 2019;(7):22-28. doi:10.35761/reesme.2019.7.03

30. Figueiredo PPV, Soares AR, Macena C, Santos HL, Magalhães PRB, Freitas PS. Justificativas para automutilação: estudo exploratório com adolescentes de escolas municipais da cidade do Recife. Rev Hum@nae [Internet]. 2019 [cited 2020 May 15];13(1):1-16. Available from: http://humanae.esuda.com.br/index.php/humanae/article/view/ 671/224\#

31. Silva AC, Botti NCL. Na investigation on self-mutilation in a group of the social network Facebook. SMAD, Rev Eletrôn Saúde Mental Alcool Drog. 2018;14(4):203-10. doi: 10.11606/issn.1806-6976.smad.2018.000355

32. Karanikola MNK, Lyberg A, Holm AL, Severinsson E. The Association between deliberate self-harm and school bullying victimization and the mediating effect of depressive symptomsand self-stigma: a systematic review. Biomed Res Int. 2018;2018:1-36. doi: 10.1155/2018/4745791

33. Almeida RS, Crispim MSS, Silva DS, Peixoto SPL. A prática da automutilação na adolescência: o olhar da psicologia escolar/educacional. Cad. Grad.Ciênc. Hum. Soc. Unit [Internet]. 2018 [cited 2020 May 16];4(3):147-60. Available from: https://periodicos.set. edu.br/index.php/ fitshumanas/article/view/5322

34. Claes L, Luyckx K, Baetens I, Van de Ven M, Witteman C. Bullying and victimization, depressive mood, and non-suicidal self-injury in adolescents: the moderating role of parental support. J Child Fam Stud. 2015;24(11):3363-71. doi: 10.1007/s10826-015-0138-2 
35. Baiden P, Stewart SL, Fallon B. The role of adverse childhood experiences as determinants of non-suicidal self-injury among children and adolescentes referred to Community and inpatient mental health settings. Child Abuse Negl. 2017;69:163-76. doi:10.1016/j. chiabu.2017.04.011

36. Lev-Wiesel R, Zohar G. The role of dissociation in self-injurious behavior among female adolescentes who were sexually abused. J Child Sex Abus. 2014;23(7):824-39. doi: 10.1080/ 10538712.2014.950399

37. Tardivo LSLPC, Rosa HR, Ferreira LS, Chaves G, Pinto-Júnior AA. Autolesão em adolescentes, depressão e ansiedade: um estudo compreensivo. Bol Acad Paul Psicol. [Internet]. 2019 [cited 2020 May 18];39(97):159-69. Available from: http://pepsic.bvsalud.org/pdf/bapp/ v39n97/a02v39n97.pdf

38. Thomassin K, Marion CG, Venasse M, Shaffer A. Specific coping strategies moderate the link between emotion expression: déficits and nonsuicidal self-injury in na inpatient sample of adolescents. Child Adolesc Psychiatry Ment Health. 2017;11(1):11-21. doi:10.1186/ s13034-017-0158-3

39. Reis MV. Automutilação: o encontro entre o real do sofrimento e o sofrimento real. Polêm!ca 2018;18(1):50-67. doi: 10.12957/ polemica.2018.36069

40. Bježančević M, GroznicaHržić I, Dodig-Ćurković K. Self-injury in adolescents: a five-year study of characteristics and trends. Psychiatr Danub. 2019;31(4):413-420. doi:10.24869/psyd. 2019.413

41. Fonseca PHN, Silva AC, Araújo LMC, Botti NCL. Autolesão sem intenção suicida entre adolescentes. Arq Bras Psicol[Internet]. 2018 [cited 2020 May 19];70(3):246-58. Available from: http://pepsic.bvsalud.org/pdf/arbp/v70n3/17.pdf 